\title{
Smart City Participation: Dream or reality? A comparison of participatory strategies from Hamburg, Berlin \& Enschede
}

\author{
Ton A.M. Spil, Robin Effing and Jaron Kwast \\ University of Twente, P.O. Box 217, 7500 AE Enschede, The Netherlands. Saxion \\ University of Applied Sciences, P.O. Box 70.000, 7500 KB Enschede, The Nether- \\ lands. \{ \\ a.a.m.spil@utwente.nl r.effing@utwente.nl \}
}

\begin{abstract}
Urbanization is forcing local government to revisit their way of communicating with citizens. By using Information Technology, cities can become smarter, more livable and more sustainable. The purpose of this study is to identify critical success factors for local government regarding smart city strategy and participation. The literature study consists of concepts such as smart city, participation and digital strategy. The qualitative study shows that the city of Hamburg defined a digital vision while the other two cities lacked setting such strategies. Bottom-up planning was their primary approach for smart city activities. Regarding the topic of participation we recognize that Hamburg can be recognized as a best practice example. Although the participatory practices were still in its infancy, they showed promising results. Remarkably, all three cities stress the importance of collaboration of different types of stakeholders. The quadruple helix structure ensures effective participation of citizens, companies, universities and government.
\end{abstract}

Keywords: Smart Cities, Participatory Governance, Intelligent city, Digital Strategy, Urban planning.

\section{Introduction}

In 2050, about two-thirds of the world population will live in cities [1,2]. The urbanization rate of cities within the European Union even exceeds that. In the year 2010, already $75 \%$ of all EU citizens were living in urban areas and it is anticipated that in the year 2050 this number will increase to approximately $85 \%$ [3].

However, increasing urbanization provides the world with new challenges. Challenges include providing affordable living space, environmental care, health conditions, and the protection of human rights $[4,5]$. Cities include many different actors that influence the city future. The focus of this paper is the topic of participation. Cities and their local government layers need to interact closely with their citizens, companies and other stakeholders. In many societies, the role of the government is changing from a leading authority to a contributory partner [5]. However, local city government struggles with keeping up with new technology trends. One of the underlying 
reasons is that existing regulations and laws do not effectively support the implementation of new technologies [6]. People, companies and public authorities can now easily connect and cooperate via the Internet and social media more efficiently than ever before [7]. The transformation of governance is changing towards more co-creation of all stakeholders [8]. This paper aims to synthesize the topics of digital strategy [9] and participatory governance from empirical cases [8]. This research paper is structured as follows. Firstly, a literature review will be presented including related concepts and literature gaps. Secondly, the chosen methodology for retrieving qualitative information is explained. Thirdlu, we present qualitative findings from the three cities and describe their e-participation strategies and implementation experiences. Finally, we will analyze these cases and draw some important conclusions.

\section{Theoretical background}

\subsection{Structured literature research method}

First, the keywords related to the topic were defined: smart city, governance, government, strategy and success factors. The database Scopus was used to search relevant literature. The result of the first queries resulted in a list of over 500 items. The results were limited to both conference papers and articles in order to exclude other document types. This resulted in 420 items. After careful reading of the title, abstract and keywords, 22 publications were identified as relevant for our study. This was a useful set to study and this led to the development of this theoretical background section.

\subsection{The smart city concept}

In recent years, a new city model, called smart city, has emerged and has gained attractiveness among many scholars [1,3,7,8,10-14]. As Van den Bergh and Viaene [13] have pointed out, the smart city concept evolved from already existing concepts such as eco-city, digital city and wireless city. The concept of smart city is not completely a new concept. In 1989, Castells [15] already mentioned the importance of an informational city and the potential power of technology for reshaping the social life in our cities. In the last decades, various innovative city concepts have entered the policy discourse such as sustainable city, green city, livable cities, digital cities, intelligent cities, knowledge cities, information cities and resilient cities [11]. As Zubizarreta et al. [14] propose, the smart city model could help addressing the main challenges of cities and attempts to avoid the new issues that will come. Those challenges include population- related problems, mobility, energy and environmental issues. Some authors claim that the smart city concept will eventually improve the city regarding social, environmental, economic and sustainable performance [16,17]. A city has to interrelate social, economic and environmental dimensions with each other to keep the overall city in balance and create benefits for all stakeholders [11]. According to Caragliu et al. [3] a city is smart: "when the investment in human and social capital and traditional (transport) and modern (ICT) communication infrastructure fuel sustainable economic growth and a high quality of life, with a wise management of natural resources, through participatory governance". There "is neither a single template of framing it, nor a-one-size-fitsall definition" on what a smart city should look like [18]. For example, smart cities in Japan have been focusing on a technical-intensive approach such as using smart grid technologies for energy 
control [8]. In Europe, cities such as Amsterdam, Copenhagen, Manchester and Milan were combining both the technological approach with a more citizen-centric approach [13].

\subsection{Participation in cities}

Participation includes all activities that are conducted voluntarily, without a statutory obligation to involve citizens in the political decision-making process [19]. Informal participation practices can be used in addition to formal practices or used separately for individual projects, but not as a replacement for formal participation [20]. Government project requirements could be met more effectively by increasing informal ways of participation [20]. This way of including citizens can be considered as more discursive and cooperative since citizens are able to exchange their opinions among each other and get in touch with other stakeholders involved. A wide range of informal participation tools is available such as stakeholder workshops, citizen juries, focus groups, electrical forums, web polling, public conversations, participatory budgeting, study circles and collaborative policy making [21]. A shift from formal to informal participation can be considered as a shift from hierarchical structures to dialog-oriented participation practices [20]. As companies are increasingly changing their management systems to bottom-up approaches, government want to adopt a similar change $[1,7,8]$. The premise for effective governance in smart cities is that, by having the right information at the right time, citizens can be included in decision making. That eventually results in an increased quality of life for residents and the overall sustainability of the city [22]. However, local city councils and city administration officials still struggle to decide when citizens should get involved in political decisionmaking and to what extent they should be involved [23].

\subsection{Digital strategies for cities}

In recent years, the rise of Web 2.0 and social media has greatly changed the way people communicate with each other [24-26]. Because of the many developments in the field of Information and Communication Technology (ICT), it should be easier for municipalities and citizens to communicate with each other [27, 28]. ICT provides citizens with new opportunities to create user generated content and exchange it via social media [29]. For government "it is necessary to change government perspective [of the citizens] from a content consumer to a content producer" [30-32]. ICT is considered by many scholars as a powerful means to promote and improve public participation [8]. There is still significant change that needs to happen within the government because traditional modes of public participation like public meetings are not beneficial according to Evans-Cowley and Hollander [33]. Traditional modes are limited in their scope and duration and therefore limited in their learning process. Public knowledge can enhance the outcome of projects that have a reason for citizen engagement [34]. Many cities keep improving their digital performance and move many services from offline media to online media. ICT is being employed for involving citizens in the decision-making process [28]. In many cases, different branches of the government initialiate different ICT initiatives. As a result, there is a lack of a central point of overview where citizens can identify all current participation opportunities [19]. Generally it is expected that the input that was generated by asking the input of citizens enriches the decision-making process [8] , eventually leading to a better outcome of the project. Therefore, the use of ICT will become even more important in the future [21]. Moreover, new ICT strategies 
that make use of the Internet provides government with a more cost-effective way of public administration [19, 27]. The ICT infrastructures in current cities support and enable the concept of smart governance [35]. Particularly social media is expected to play a key role in digital participation because of its unique opportunities for fostering public debates and exchanging opinions [19]. However, many city government employees still lack skills to effectively employ these social media for within the decision-making process [36].

\section{$2.5 \quad$ E-participatory smart cities}

This paper uses the concepts of Effing and Groot [37] and Spil et al. [9, 51] in the analysis to combine the degree of engagement that citizens have with government, citizen or network initiatives of a smart city that can be taken in order to improve and develop the overall city to become smart.

Citizens are increasingly engaged into the concept through their mobile devices that enable direct involvement [8]. E-commitment [37] can be seen as part of the engagement [9]. To be engaged the cities have to identify the target groups, set their goals and determine the channels that they want to use. Furthermore, is it important for cities to integrate their habitants since they are the protagonist of a city, the most important feature, and belong to the site and everything that is being done concerns them [14].

Governments need to enable the capacity to be able to manage the amount of new possibilities of participation [9]. Cities need to adapt to the fact that citizens want to be able to actively take part into governmental decisions [38]. They have to allocate resources, decide and communicate policies. Cities have already implemented many online participation tools, but there is still capacity in integrating real time data from sensors and activators [39] into participatory governance. Overall smart cities have a high interest in integrating sensors, smart devices and real-time data into every aspect of human life [40]. Cities have often not realized the potential of participatory governance, and is still an underestimated factor [41]. Also the concept of the quadruple helix is increasingly important [42] since the innovation benefits from the involvement of citizens, companies, government and universities.

Finally Cities have to evaluate their digital strategy [9]. Although it is hard to measure Return on Investment quantitatively, the cities can monitor and listen to its citizens and cities need to use evaluation tool to measure this.

\section{Results}

\subsection{Empirical research method}

This study consists of three cases that were selected for the following reasons. First, we searched for best practice examples. Hamburg is considered as one of the smartest and most livable cities in Germany according to several rankings [43-45]. A case study of Hamburg was conducted. A contemporary phenomenon (a "case") was studied in-depth within its real-world context. Hamburg has been classified as a critical case as former research has shown, that it provides a critical 
reason to investigate Hamburg more intensively when this holds true according to Yin [46]. Especially when the boundaries between phenomenon and context may not be clearly evident, a case study can create new insights [46]. Remenyi and Williams [47] claim that a single case study is quite limited in business and management research for drawing general conclusions. Therefore we selected two additional cities for case study research. These are Berlin, the capital and largest city of Germany, and the city of Enschede, in the Eastern part of the Netherlands, with the potential to become a smart city. Eisenhardt and Graebner [48] claim that insights drawn from cases often result in highly cited publications. Furthermore, Zainal [49] states that case studies, in their true essence, are aimed at investigating contemporary real-life phenomenon through detailed contextual analysis of a limited number of events or conditions and their relationships. The qualitative interviews were carried out with two employees of each city. They were, at the time of writing, working on the smart city development at the municipalities of the included cities. All interviewees were highly familiar with the main concepts and had practical knowledge to serve the potential of this research. For this qualitative part of the study, we conducted semi-structured interviews. This type of interview combines the benefits of both unstructured interviews and structured interviews. On the one hand, these interviews served as evidence for the validation of our literature findings. On the other hand, these interviews were open for the possibility for adding additional knowledge regarding the subject matter of smart cities [50]. The interviews were recorded and transcribed to warrant that all information said was included in this paper.

\subsection{Hamburg}

Respondent 2 (R2) mentioned: "everybody is talking about the smart city concept. However, the ultimate smart city is an utopia and does not exist". The smart city concept is not a single concept. It includes many different ways for cities to become smart. In January 2015, a visionary paper about Hamburg's digital future, entitled "Digitale Stadt" (digital city), was approved by The Senate of the Free and Hanseatic city of Hamburg. .Within this vision it was especially important to "establish an innovation climate that enables citizens to make public data openly accessible and support companies and institutions in networking" (R1) as well as "achieving a higher quality of living" (R2). In the online communication and public services, there is great potential to exploit since offline communication channels are already exploited to the maximum within the city of Hamburg (R2). Therefore, the Internet can serve as a new opportunity for increasing the number of participating citizens. Furthermore, Respondent 2 stressed that it is important for governments to increasingly work in a citizen-centric way and try to reach out for citizens. For example, when citizens say that "if Hamburg sends a multiple-choice list on my mobile device, then I am willing to respond" (R2), then Hamburg is obligated to serve them multiple-choice lists to increase their participation.

In recent years, governance has changed and became a bottom-up approach. Citizens are empowered by letting them actively engage in the decision-making process (R1). Information flow and accessability of information is considered as important in Hamburg. Therefore, the city of Hamburg has decided to implement the "Transparenzgesetz" (transparency law) in 2012. This includes creating an online platform, the so called "Transparenzportal" (transparency portal), in order to give the public online access to data created by the local government.

Another tool Hamburg is using to drive up innovation with companies is embedded into the Transparenzportal and provides open data for companies to use. Yet companies have not showed 
much interest in these datasets. Predominantly, the academic stakeholders are interested in using those datasets (R2).

Additinally, Hamburg wants to promote the implementation of various informal participation tools in the decision-making processes. The city of Hamburg already recognized this trend and gained some positive results from using informal participation practices. For example, the "Weltquartier Wilhelmsburg" and the "Hamburger Deckel". Through the early recognition of the value of informal participation, one best practice has evolved over time (R2). An important smart strategy is: "including citizens as early and as active as possible" (R1), even before the projects are tendered to business... Everything regarding participation in Hamburg, including phase zero, is joined in the online platform called Stadtwerkstatt. The Stadtwerkstatt "is an integral part of citizen participation" (R1). This is considered as the "central place to receive information" (R1) regarding projects initiated by the government. Another important topic of digital participation is the use of social media, However, effective social media use is very time-consuming and many resources are necessary. Employees are in charge of the content and serve as contact persons. "The Senate of Hamburg is using many social media platforms and online appearances" (R1). However, there is not enough budget to participate on social media for projects regarding decision making for special projects (R2).

An important part of online tools is that they empower citizens much more than offline tools do (R2). Empowering is a very important part of smart governance and needs to be implemented in one way or another. But as the interviews showed, "real empowerment does not exist since municipalities are always in need for expert knowledge" (R2). However, it is important that the government should not limit citizens in their creativity or manipulate their decision-making abilities (R2). Hence, empowerment is important but it needs to be tailored for the citizens in such a way that it does not disable their creativity and free expression.

Network collaboration represents another key part of the smart city concept. Hamburg tries to encourage innovation through a variety of collaborative practices. One possibility is "to encourage innovation using the triple helix structure, which brings together companies, universities and the government" (R1).

\subsection{Berlin}

According to Berlin's Smart City Strategy[A1], the city can only be smart if the following three aspects are fulfilled:

1. The city combines various sources of information;

2. The city achieves a significant increase in efficiency and use of resources through integrated approaches and;

3. The city actively involves citizens and investors in the process of shaping the city in order to make it attractive, viable for the future, resilient and dedicated to the common good, eventually increasing the quality of life..

The smart city strategy is a proposal of actions that Berlin needs to undertake in order to become a smart city. This strategy plan includes all aspects that appear in the smart city conceptualization: environment, safety, innovation, network, infrastructure and social participation. In addition, they emphasize the goals of making Berlin more competitive as a capital region internationally and the marketing of Berlin's innovativeness. The actions proposed are aimed at digitalizing the way Berlin's government and public administration works. However, an implementation plan or 
schedule is lacking. When asked about the most important aspects of the Smart City Berlin, the respondent 3 (R3) mentioned the Smart City Berlin Network. "This network has 100 members, comprising innovative companies and research institutes in Berlin. They already developed a lot of creative ideas for applications in order to make the city smarter". She says, so far these applications have only been applied abroad and Berlin has not implemented their own ideas yet. The city's senate was too constrained for applying a strategy in order to test it. As for the social aspect of the smart city, the smart city strategy Berlin supports the idea of earlier mentioned literature: the citizens of Berlin are the most important component for making the strategy work. It argues that, for digital strategies and applications to be successful, citizens of Berlin have to approve of them. In order to achieve that, marketing has to convince them of the strategies' usefulness, for which they want to communicate with citizens via social media platforms. The strategy proposes ways to enable e-participation, which will be elaborated on in the next section. However, an implementation plan was lacking.

The most elaborated e-participation strategy in Berlin is the use of Open Data as an innovation strategy. The webpage enables citizens who are interested in Berlin's city development and decisions about all senate solutions, official documents and dates regarding all components of the capital. However, for empowering, Berlin's smart city e-participation strategy "Mein Berlin" (My Berlin) is presented in the Smart City Strategy Berlin as Berlin's main participatory instrument for the future. Furthermore, Berlin's Smart City Strategy suggests that their open data policy, guided towards transparency and open decision-making, will encourage citizen participation in the future. Nonetheless, the same chapter of the strategy states that, no matter how evolved these platforms might be, it is important that they do not replace democratic decision making. As an agenda for 2016, a unifying platform of contact was planned to facilitate administrative services and "create a unified point of contact for citizens and business". This represented a digital strategy for citizens to involve themselves with the government, but was still lacking the participatory element.

One of the innovations that came from companies working on smart governmental solutions is called the "DIALOG BOX". It was found during the analysis of Berlin's governmental webpages. The innovation claims to be an ideal way for communication between citizens and government. It is software that was developed for the sole purpose of citizen participation. Nonetheless, there is no evidence for a link with Berlin's smart city strategy, neither a sign of collaboration (R3). This suggests that the progress of implementation of these strategies is taking place quite slowly and an implementation schedule is lacking. This was also confirmed by respondent 3 . Nevertheless, she emphasized that the Smart City Berlin Network is regularly discussing strategies and proposals to make participatory action reality. This means that in their annual meetings, they consider the Smart City Berlin Strategy as a basis of their actions and they come up with ideas to implement e-participation, based on the senate's strategy.

The only informative digital platform that is implemented from the strategy is Berlin's Open Data page, giving citizens access to administrative documents and data. However, this platform does not provide visitors with any participatory functions for commenting and sharing their opinions. The beta version of "Mein Berlin" is the closest Berlin gets to an empowering e-participation strategy at this moment. According to R3, the chamber of Industry and Commerce Berlin and other network partners expressed critique towards the lacking implementation schedule. Her department did publish a brochure stating that participatory instruments need to be implemented. 
She further explained that the Smart City Berlin Network also proposed solutions for participatory action. However, in order to implement a strategy, the final decision lies within the senate department of urban development and environment. During an interview with the smart city strategist R4 of that department, it was expressed that any kind of such a strategy in practice would be "Zukunftsmusik" (Still up in the air) in Berlin and that there will be no implementation regarding that matter soon. This respondent also made very clear, that there is nothing to talk about regarding that matter. According to R3, the important missing piece in this endeavor right now is an implementation plan with exact steps to take in the future, published by the senate and their strategists.

\subsection{Enschede}

Enschede describes a smart city as: making the city smarter, with smart people and doing things smarter as a government". The key questions of the municipality are: how can we make better use of the already available data? "And how can we use technology in a better way?" This can then be used for monitoring, user experience, and the development of policies. Enschede did focus on the opportunities of the use of big data. They described their key challenge as: How can we use the already available data in a better, more smarter way for creating policies?" Another project is focusing on the city centre that is employed as a living-lab in cooperation with local universities. In Enschede, collaboration with large companies was mostly avoided, since this could lead to a vendor lock-in. Instead, local businesses were contacted and involved. According to respondent 5 , the municipality shifted towards a bottom-up approach, starting with small projects in the Enschede community. There are entrepreneurs and citizens working on this. Their quest according to respondent 5 is: "how can we make a transition in means of communication in order to activate these people?"

Enschede is labelling itself as a smart city (R5). "We are focussing on this topic and we recognise the importance. We make room for it and act on this topic. We are in anyway planning on providing more open data. (R5)" An example of this is the cooperation with the German city of Heidelberg and the American city of Palo Alto in Silicon Valley. Furthermore, the municipality is a member of different collaboration platforms regarding smart city strategies such as the Open and Agile Smart Cities Initiative. The interviewee did explore the subject of smart city and what it can do for the city. However, a smart city strategy was at the time of research not defined in a policy plan. Furtermore, the implementation budget for smart cities was relatively small. Instead, investments are part of on-going maintenance and existing policy programs: Investments are always required within cities. For example Enschede has recurring investments in street lights, asphalt or traffic lights giving them the opportunity to innovate.. "If you think smart on those moments about what you want and what is possible, you can invest in new technology that might not be needed now, but that can be uses in the near future. (R5)"

Enschede currently does not have a detailed vision on smart city. The respondent 6 had defined something that could be seen as a vision, but this is not really useful according to the interviewee: "from the moment you write down your vision it is obsolete". For now they want to focus on participating citizens, knowledge centres and businesses: "we want to give space to companies to do things, create a living-lab environment. Not only for knowledge institutes, but also for businesses, to make things happen." 


\section{$4 \quad$ Analysis}

In this section, we compare the three cities by using relevant digital strategy models $[9,37,51]$. A digital strategy cannot be effective without engagement of people. While both the dialog box in Berlin and "Enschede stad" provide us with participatory examples, they still lack real commitment. In Hamburg, they use social media in an effective way for engaging their citizens, companies and knowledge institutes. E-commitment is quite a remarkable practice in Hamburg but is still starting up in the "Stadtwerkstatt" environment. Effing and Groot [37] emphasise the importance of commitment as part of the smart city. "Mein Berlin" is a good example but you could expect more similar initiatives in a big capital city such as Berlin. In Enschede, small companies are involved for building commitment. We also recognize the quadruple helix collaboration structure being beneficial there. In Hamburg, there was actually a digital strategy in place but it was not incorporated in a formal governance cycle. Evaluation of the smart city progress was lacking as shown in table 1. In Berlin and Enschede, the respondents did not mention a specifically defined digital strategy. All three cities formulated goals for their smart cities. However, these goals were not quantified and difficult to measure. In theory, enabling citizens by digital solutions means much more than having a website. The aspect of effective enabling citizens and companies requires also resources and policies as part of the strategy [9]. Yet all respondents refer to the basic website of the cities when they talk about enabling. A share of the included respondents stressed that the capacity and resources of the "smart" departments were quite limited. Finally, evaluation of progress regarding the smart city strategy is not specifically developed at these three cities [9]. The emphasis of the smart cities Hamburg, Berlin and Enschede clearly was aimed at developing digital engagement with the public as first priority.

Table 1 - Analysis overview

\begin{tabular}{|l|l|l|l|}
\hline $\begin{array}{l}\text { City/Stage of } \\
\text { participation }\end{array}$ & Enable & Engage & Evaluate \\
\hline Hamburg & Hamburg.de & $\begin{array}{l}\text { Social media } \\
\text { Stadtwerkstatt }\end{array}$ & None \\
\hline Berlin & Berlin.de & $\begin{array}{l}\text { Dialog box } \\
\text { Mein Berlin }\end{array}$ & None \\
\hline Enschede & Enschede.nl & $\begin{array}{l}\text { Enschede stad } \\
\text { Small companies }\end{array}$ & None \\
\hline
\end{tabular}

$6 \underline{5}$

Conclusion

Cities in Europe are still struggling with the smart city concept. In most cities, digital strategies and visions still have to be developed. Furthermore, the evaluation and monitoring of smart city results is not yet operational. As a result, the government policy cycle is not working effectively. However, there is awareness that the quadruple helix collaboration structure is necessary; involving citizens, companies, knowledge institutes and government for creating and fostering a livable society. 
The empirical results show that smart cities are still a dream but that reality is winning fast and the possibilities seem endless. Hamburg is a pioneering city with participation tools at the operational level and their experiences can lead the way for other cities, but experiences and learning are not yet developed well.

As a theoretical contribution, evaluation should be added to the smart city concept model to create a knowledge-learning loop and to create a basis for future digital strategies. The new concept encompasses: Enablement, Engagement and Evaluation.

Future studies have to address evaluation, can explore ICT more specifically the Internet of Things [51] and can explore more cities for a more general view on smart cities .

\section{Acknowledgements}

We express our gratitude for students who have contributed to this paper. We want to thank Julia Steinke and Johann Rick Harms who helped collecting case material. Their thesis projects were part of the broader research collaboration regarding smart city strategy of both University of Twente and Saxion University of Applied Sciences (Project TFF Brid.ge).

\section{References}

1. Niaros, V. (2016). Introducing a taxonomy of the "smart city": Towards a commonsoriented approach?

2. World Health Organization (2016). Global Report on Urban Health, equitable cities for sustainable development. Retrieved on April 30, 2017 from:

www.who.int/kobe_centre/measuring/urban-global-report/ugr_full_report.pdf

3. Caragliu, A., Del Bo, C., \& Nijkamp, P. (2011). Smart cities in Europe. Journal of urban technology, 18(2), 65-82.

4. Cohen, B. (2006). Urbanization in developing countries: Current trends, future projections, and key challenges for sustainability. Technology in Society, 28(1-2), 6380. doi:http://dx.doi.org/10.1016/j.techsoc.2005.10.005

5. Gil-Garcia, J. R., Pardo, T. A., \& Nam, T. (2015). What makes a city smart? Identifying core components and proposing an integrative and comprehensive conceptualization. Information Polity, 20(1), 61-87.

6. Kettl, D. F. (2015). The transformation of governance: Public administration for the twenty-first century: JHU Press.

7. Schaffers, H., Komninos, N., Pallot, M., Trousse, B., Nilsson, M., \& Oliveira, A. (2011). Smart Cities and the Future Internet: Towards Cooperation Frameworks for Open Innovation. Future internet assembly, 6656(31), 431-446.

8. Granier, B., \& Kudo, H. (2015). How are citizens involved in smart cities? Analysing citizen participation in Japanese "Smart Communities". Information Polity(Preprint), 1-16.

9. Spil, Ton A.M., Effing, R. \& Both, M. (2016). Enable, Engage and Evaluate: a social media strategies canvas tool based on the European airline industry. IFIP8.6 conference proceedings, Swansea, Great Britain.

10.Chourabi, H., Nam, T., Walker, S., Gil-Garcia, J. R., Mellouli, S., Nahon, K., . . . Scholl, H. J. (2012). Understanding smart cities: An integrative framework. Paper presented at the System Science (HICSS), 2012 45th Hawaii International Conference on.

11.De Jong, M., Joss, S., Schraven, D., Zhan, C., \& Weijnen, M. (2015). Sustainablesmart-resilient-low carbon-eco-knowledge cities; making sense of a multitude of 
concepts promoting sustainable urbanization. Journal of Cleaner Production, 109, 25-38.

12.Hollands, R. G. (2008). Will the real smart city please stand up? Intelligent, progressive or entrepreneurial? City, 12(3), 303-320.

13.Van den Bergh, J., \& Viaene, S. (2016). Unveiling smart city implementation challenges: The case of Ghent. Information Polity(Preprint), 1-15.

14.Zubizarreta, I., Seravalli, A., \& Arrizabalaga, S. (2015). Smart City Concept: What It Is and What It Should Be. Journal of Urban Planning and Development, 04015005.

15.Castells, M. (1989). The informational city: Information technology, economic restructuring, and the urban-regional process: Blackwell Oxford.

16.Network, S. G., \& Association, I. C. C. M. (2002). Getting to smart growth: 100 policies for implementation: Smart Growth Network.

17.Network, S. G., \& Association, I. C. C. M. (2003). Getting to Smart Growth II: 100 more policies for implementation: Smart Growth Network.

18.Albino, V., Berardi, U., \& Dangelico, R. M. (2015). Smart cities: Definitions, dimensions, performance, and initiatives. Journal of urban technology, 22(1), 3-21.

19.Vogt, S., Förster, B., \& Kabst, R. (2014). Social Media and e-Participation: Challenges of Social Media for Managing Public Projects. International Journal of Public Administration in the Digital Age (IJPADA), 1(3), 85-105.

20.Klages, H., \& Vetter, A. (2013). Bürgerbeteiligung auf kommunaler Ebene: Perspektiven für eine systematische und verstetigte Gestaltung (Vol. 43): edition sigma.

21.Vogt, S., \& Haas, A. (2015). The future of public participation in Germany: Empirical analyses of administration experts' assessments. Technological Forecasting and Social Change, 98, 157-173.

22.Khansari, N., Mostashari, A., \& Mansouri, M. (2014). Impacting sustainable behavior and planning in smart city. International Journal of Sustainable Land Use and Urban Planning (IJSLUP), 1(2).

23.Rowe, G., \& Frewer, L. J. (2000). Public participation methods: A framework for evaluation. Science, technology \& human values, 25(1), 3-29.

24.Greenhow, C., Robelia, B., \& Hughes, J. E. (2009). Learning, teaching, and scholarship in a digital age Web 2.0 and classroom research: What path should we take now? Educational researcher, 38(4), 246-259.

25.Hoffman, D. L., Novak, T. P., \& Venkatesh, A. (2004). Has the Internet become indispensable? Communications of the ACM, 47(7), 37-42.

26.Leiner, B. M., Cerf, V. G., Clark, D. D., Kahn, R. E., Kleinrock, L., Lynch, D. C., . . . Wolff, S. (2009). A brief history of the Internet. ACM SIGCOMM Computer Communication Review, 39(5), 22-31.

27.Åström, J. (2001). Should democracy online be quick, strong, or thin? Communications of the ACM, 44(1), 49-51.

28.Medaglia, R. (2012). eParticipation research: Moving characterization forward (2006-2011). Government Information Quarterly, 29(3), 346-360. doi:http://dx.doi.org/10.1016/j.giq.2012.02.010

29.Kaplan, A. M., \& Haenlein, M. (2010). Users of the world, unite! The challenges and opportunities of Social Media. Business horizons, 53(1), 59-68.

30.Brabham, D. C. (2009). Crowdsourcing the public participation process for planning projects. Planning Theory, 8(3), 242-262.

31.Ornebring, H. (2013). THE CONSUMER AS PRODUCER* OF WHAT? Usergenerated tabloid content in The Sun (UK) and Aftonbladet (Sweden). The Future of Newspapers, 142 
32.Rebillard, F., \& Touboul, A. (2010). Promises unfulfilled?'Journalism 2.0’, user participation and editorial policy on newspaper websites. Media, Culture \& Society, 32(2), 323-334

33.Evans-Cowley, J., \& Hollander, J. (2010). The new generation of public participation: Internet-based participation tools. Planning, Practice \& Research, 25(3), 397-408.

34.Schweizer, P.-J., Renn, O., Köck, W., Bovet, J., Benighaus, C., Scheel, O., \& Schröter, R. (2014). Public participation for infrastructure planning in the context of the German "Energiewende". Utilities Policy.

35.Scholl, H. J., \& AlAwadhi, S. (2016). Creating Smart Governance: The key to radical ICT overhaul at the city of munich. Information Polity(Preprint), 1-22.

36.Dameri, R. P. (2013). Searching for Smart City definition: a comprehensive proposal. International Journal of Computers \& Technology, 11(5), 2544-2551.

37.Effing, R., \& Groot, B. P. (2016, September). Social Smart City: Introducing Digital and Social Strategies for Participatory Governance in Smart Cities. In International Conference on Electronic Government and the Information Systems Perspective (pp. 241-252). Springer International Publishing.

38.Städtetag, D. (2013). Culture of Participation in Integrated Urban Development: Working Paper of the Working Group on Public Participation by the German Association of Cities: Deutscher Städtetag.

39.Zygiaris, S. (2013). Smart city reference model: Assisting planners to conceptualize the building of smart city innovation ecosystems. Journal of the Knowledge Economy, 4(2), 217-231.

40.Cretu, L.-G. (2012). Smart cities design using event-driven paradigm and semantic web. Informatica Economica, 16(4), 57.

41.Bingham, L. B., Nabatchi, T., \& O'Leary, R. (2005). The new governance: Practices and processes for stakeholder and citizen participation in the work of government Public administration review, 65(5), 547-558.

42.Afonso, Ó., Monteiro, S., \& Thompson, M. J. R. (2010). A growth model for the quadruple helix innovation theory.

43.Cohen, B. (2014). The 10 Smartest Cities In Europe. Retrieved from http://www.fastcoexist.com/3024721/the-10-smartest-cities-in-europe/8

44.Mercer. (2016). Quality of living ranking Retrieved from https://www.imercer.com/content/mobility/quality-of-living-city-rankings.html - list

45.Numbeo. (2016). Quality of Life Index 2016. Retrieved from $\mathrm{http}: / / \mathrm{www}$. numbeo.com/quality-of-life/rankings.jsp

46.Yin, R. K. (2013). Case study research: Design and methods: Sage publications.

47.Remenyi, D., \& Williams, B. (1998). Doing research in business and management: an introduction to process and method: Sage.

48.Eisenhardt, K. M., \& Graebner, M. E. (2007). Theory building from cases: Opportunities and challenges. Academy of management journal, 50(1), 25

49.Zainal, Z. (2007). Case study as a research method. Jurnal Kemanusiaan, 9.

50.Hove, S. E., \& Anda, B. (2005). Experiences from conducting semi-structured interviews in empirical software engineering research. Paper presented at the Software metrics, 2005. 11th ieee international symposium.

51.Spil, Ton AM, Pris, M \& Kijl, B (2017). Exploring the BIG Five of e-leadership by developing digital strategies with mobile, cloud, big data, social media, and the Internet of things. E-proceedings IC Management Leadership \&Governance, Johannesburg South Africa. 